\title{
EFFECTS OF AMENDMENTS, SOIL ADDITIVES, AND IRRIGATION ON TREE SURVIVAL AND GROWTH
}

\section{by Edward F. Gilman}

\begin{abstract}
During the first and second year after transplanting into good soil, there was no apparent benefit from adding amendments to the backfill soil around newly planted $5 \mathrm{~cm}$ (2 in.) caliper live oaks (Quercus virginiana Mill.), nor was there a benefit from applying liquid additives over the root ball. Top growth in the first 2 years after planting was not enhanced on trees with amendments added to the backfill soil compared to the control. In the first growing season following planting, trees irrigated frequently ( 3 times per week for 38 weeks) grew about twice as fast as those irrigated only during the first 3 months after planting. There was no lingering effect of irrigation on top growth rates once irrigation ceased. Trunk diameter and height growth on trees treated with paclobutrazol (Profile ${ }^{\mathrm{TM}} 2 \mathrm{SC}$ ) was less than on trees in all other treatments due to the growth-regulating effect of paclobutrazol. Root growth in the backfill soil was not affected by soil amendments added to the backfill soil at planting and was not affected by irrigation after planting in 5 of the 7 treatments.

Key Words. Backfill amendments; transplanting; planting; root growth; landscape; paclobutrazol; hydrogels; humic substances.
\end{abstract}

The influence of incorporating soil amendments into the backfill soil around newly planted trees and shrubs has been studied in several climates. Numerous soil types, plant species and sizes, and nursery production methods have been tested with varying results. Addition of hydrophilic gel, peat, and slow-release fertilizer in soil inside fabric field-grown container seedling green ash (Fraxinus pennsylvanica) had little effect on growth in the nursery (Henderson-Cole and Hensley 1992).

No benefit to silver maple (Acer saccharinum L.) was derived from the use of soil amendments in backfill soil either with a clay loam soil or very poor silt loam subsoil (Schulte and Whitcomb 1975). In fact, pine bark as a soil amendment was detrimental to growth unless fertilizer was applied to offset the nitrogen tie-up by microorganisms. Trees growing in soils amended with peat moss developed a more fibrous root system than trees in all other treatments. However, the fact that the roots did not develop into the surrounding soil, as was the case with all other treatments, may mean the trees would be more susceptible to drought. These data combined with that from other studies (Pellet 1971; Corley 1984; Kelting et al. 1998; Ferrini and Nicese 2002) do not support use of soil amendments or liquid additives in backfill soil in the establishment and growth of newly planted trees, at least in good soil.

Smalley and Wood (1995) also found increased root density within the backfill soil after amending it when planting balled-and-burlapped red maple (A. rubrum) into clay soil. But aged pine bark mixed 50:50 with backfill soil induced nitrogen deficiency symptoms and reduced shoot growth during the first year. Shoot growth on trees with amended soil was similar to growth on trees backfilled with native soil 2 years after planting. Authors concluded that the data support use of native soil in backfilling planting holes.

There are several studies on amending backfill soil around shrub species. Root growth of container-grown Pittosporum tobira Thunb. 6 months after transplanting into a landscape with a sandy soil was greater when the backfill was amended with peat than when amended with colloidal phosphate or not amended. Neither backfill affected top or root dry weight compared to controls after 12 months (Ingram et al. 1981). Top dry weight of Juniperus chinensis L. 'Hetzii' increased with backfill amendments after 12 months but not when fertilizer was added (Ingram et al. 1981). Root and top growth on azalea (Rhododendron spp.) was significantly improved when organic amendments were added to an entire landscape bed in sandy soil (Beeson and Keller 1998). Azalea survival was dramatically improved by incorporating 5 or $10 \mathrm{~cm}$ (2 or 4 in.) of pine bark into a clay loam soil planting bed (Bir et al. 1995). Other research supports incorporating organic amendments into large planting beds to improve shrub growth and survival (Banko 1986; Bir and Ranney 1991). Inorganic soil amendments incorporated into the entire root zone have been shown to improve turf performance, but only during drought and only when the amendment comprised more than at least $40 \%$ of the soil volume (Wehtje et al. 2003).

The objective of this research was to test the effectiveness of backfill amendments, commercial products, and irrigation in minimizing water stress and increasing survival and growth after planting in the landscape.

\section{MATERIALS AND METHODS}

Three meter tall (10 ft), acorn-propagated live oak (Quercus virginiana Mill.) with an average caliper of $5.1 \mathrm{~cm}$ (2 in.) in \#15 [41 cm (16 in.) top diameter], smooth-sided plastic containers were planted between January 5 and 11, 1995, into a Millhopper fine sand (loamy, silicaceous, hyperthermic 
Grossarenic Paleudults) with less than 2\% organic matter. The site was a tree nursery for about 10 years prior to this test, so the soil was not compacted [bulk density $1.37 \mathrm{~g} / \mathrm{cc}$ $\left(0.8 \mathrm{oz} / \mathrm{in}^{3}\right)$ in the top $15 \mathrm{~cm}$ (6 in.)]. Holes were dug $76 \mathrm{~cm}$ (30 in.) wide and as deep as the root ball with a soil auger and adjusted with a shovel. Holes were spaced $3 \mathrm{~m}(10 \mathrm{ft})$ apart within rows and rows were $3.7 \mathrm{~m}$ (12 ft) apart.

The following seven treatments were applied around or on the root ball in a randomized complete block design: Terra-Sorb $®$ (potassium acrylamide hydrogel), Stockosorb $®$ (crosslinked potassium polyacrylamate/polyacrylamide copolymer), Drought Releaf® (a pulp and paper byproduct), composted yard waste, ROOTSTM (peat humic substances, sea kelp extracts, vitamin B1, co-enzymes) paclobutrazol (Profile ${ }^{\mathrm{TM}}$ 2SC), and a nontreated control. Terra-Sorb, Stockosorb, Drought Releaf, and composted yard waste were incorporated by shovel into the backfill soil as it was added to the planting hole. ROOTS and Profile 2SC were poured over the root ball after the planting hole was filled in with native backfill soil. Native soil was used around the root ball for the nontreated controls. No soil was placed over the root ball on any treatments. The root flare on all trees was located at the soil surface at planting.

Terra-Sorb [85.05 g (0.19 lb)] or Stockosorb [102.06 g $(0.22 \mathrm{lb})$ ] was evenly mixed with the backfill soil of each treated plant according to manufacturer's recommendation. In our laboratory tests, these amounts absorbed the same volume of water. Drought Releaf was added at a rate of $425.25 \mathrm{~g}$ (0.94 lb) per hole. Compost was mixed one part compost:two parts soil and this mixture was used as backfill soil. Fifty-seven grams (2 oz) of ROOTS was mixed with $7.6 \mathrm{~L}$ (2 gal) water, and $113 \mathrm{~g}$ ( $4 \mathrm{oz}$ ) of this mixture was poured over the root ball one time according to manufacturer's directions. Nine hundred mL (30.4 oz) Profile 2SC was mixed in water to make $11.3 \mathrm{~L}$ ( 3 gal), and $250 \mathrm{~mL}(8.5 \mathrm{oz})$ of this mixture was poured over the root ball [5 mL (0.17 oz) a.i./tree].

All trees were irrigated every other day with 19 L (5 gal) through January 18. Then trees were placed on one of two irrigation regimes: frequent irrigation or infrequent irrigation. Fifteen trees received each of the backfill $\times$ irrigation treatment combinations ( 7 backfill treatments $\times 2$ irrigation frequencies $\times 15$ replicates $=210$ trees $)$. After January 18, trees receiving frequent irrigation were watered with $7.6 \mathrm{~L}$ (2 gal) three times per week through October 13, 1995. A total of about $816 \mathrm{~L}$ (216 gal) irrigation was applied to each frequently irrigated tree. Trees in the infrequent irrigated plots were irrigated with $7.6 \mathrm{~L}$ ( 2 gal) only on the following dates: $1 / 26,1 / 31,2 / 2,2 / 11,2 / 17,2 / 24,3 / 3,3 / 31,4 / 2,5 / 9$, $5 / 22,6 / 3$, and $6 / 16$. A total of about $151 \mathrm{~L}$ (40 gal) was applied to the infrequently irrigated trees. April and May are fairly warm and dry months in northern Florida, U.S., where this test was conducted. All irrigation was applied over the root ball only, not outside of the root ball. No mulch was applied. Weeds were controlled in a $1.8 \mathrm{~m}(6 \mathrm{ft})$ wide strip down each row of trees with periodic applications of glyphosate.

Tree trunk diameter and height were measured periodically to evaluate growth rate after planting. A pressure bomb (Soil Moisture Inc., Santa Barbara, CA) was used to periodically evaluate tree water potential. This is a reliable method of evaluating stress after planting. Stress in five replicates was measured for each treatment combination ( 7 amendments $\times 2$ irrigation treatments $\times 5$ replicates $=70$ trees) at each measurement date. Five, ten, and fifteen weeks after planting, stress was recorded about every 2 hours dawn until dusk. Mid-day measurements were recorded on eight other dates beginning about 2 weeks after planting.

Root systems on five trees for each treatment combination ( 7 amendments $\times 2$ irrigation treatments $\times 5$ replicates = 70 trees $)$ were partially excavated in December 1996 (2 years after planting). All roots were collected from two oneeighth circumference soil volumes (one on the north side and one on the south side of the tree) as deep as the root ball [40.6 cm (16 in).] beginning at the edge of the root ball out to $12.7 \mathrm{~cm}$ ( 5 in.) away. All collected roots were in the backfill soil. Soil was washed from the roots and roots dried for 7 days in an oven at $70^{\circ} \mathrm{C}\left(158^{\circ} \mathrm{F}\right)$.

Data were analyzed using ANOVA and regression in SAS. Means were considered significant at $P<0.05$ level using Duncan's multiple range test.

\section{RESULTS AND DISCUSSION}

Two weeks after planting, trees amended with Stockosorb, Drought Releaf, and Profile that were not watered for 3 days were significantly more stressed (more negative xylem potential) than trees in nonamended backfill (data not shown); there was no difference in stress among soil amendments for trees irrigated frequently. Five (Figure $1^{*}$ ), ten (data not shown), and fifteen weeks (Figure 2) after planting, xylem potential in trees was similar for all backfill amendments, and frequently irrigated trees were less stressed than those receiving less frequent irrigation.

During the first and second year after transplanting, there was no apparent benefit from adding amendments to the backfill soil around newly planted live oaks nor was there a benefit from applying liquid additives over the root ball. Top growth in the first 2 years after planting was not enhanced on trees with amendments added to the backfill soil compared to the control (Figures 3 and 4). The controls received only the native soil present at the site as backfill.

*Figures are shown on pp. 306-310. 
Irrigation did not interact with soil amendment treatment, meaning that amendments did not affect survivability or growth of live oaks when irrigation was either minimal or plentiful after transplanting. This finding contradicts promotional literature distributed by manufacturers of many amendments but supports nearly all published studies on trees (Pellet 1971; Schulte and Whitcomb 1975; Ingram et al. 1981; Corley 1984; Smalley and Wood 1995; Ferrini and Nicese 2002).

Not surprisingly, in the first growing season (March 1995 through April 1996) after planting, trees irrigated frequently after planting ( 3 times per week for 38 weeks) grew about twice as fast (caliper and height increase) as those irrigated periodically only during the first 3 months after planting (Figures 3 and 4). Growth rate in the second growing season (April 1996 through December 1996) was similar for irrigated and nonirrigated trees (slopes were equal at $P<0.05$ ), most likely because trees were established by this time (Gilman and Beeson 1992). Past studies (Gilman 2001) also found that live oak trees often grew at the same rate once they were established regardless of the irrigation frequency they received in the first few months after planting. Irrigation simply increases survival and growth rate during the period trees receive irrigation.

Trees treated with Profile 2SC grew slower (caliper and height) than all other treatments because of the growthregulating effect of paclobutrazol. This growth regulator has been used to slow growth of trees near power lines and in other urban situations. Despite slower top growth, there was no evidence that roots grew any slower than other treatments. This suggests a change in the root:shoot ratio observed by other researchers (Watson 1996). For this reason, it has been suggested for use on newly planted trees to help them overcome transplant shock. However, reduction of transplant shock did not occur in the present study.

Root weight in the backfill soil for all amendments and additives 2 years after planting was similar to the nontreated controls. Frequently irrigated control and Stockosorb trees generated more roots in the backfill soil than trees receiving less irrigation (Figure 5). There were no other differences in root growth.

Two-hundred and seven of the 210 trees in the study survived. All dead trees died in the first 5 months after planting and were in the portion of the plot that was infrequently irrigated after planting. One tree died in each of the following treatments: Terra-Sorb, Stockosorb, and ROOTS.

\section{CONCLUSION}

In summary, $5 \mathrm{~cm}$ (2 in.) caliper trees planted from containers irrigated with $7.6 \mathrm{~L}$ ( 2 gal) of water three times each week [22.8 L (6 gal) per week] were less stressed in the first few months after planting than those irrigated about once every 10 days with $7.6 \mathrm{~L}$ ( 2 gal). However, all trees irrigated less frequently survived, except for three, and once they were established (about 8 months after planting), they grew at the same rate as trees that received frequent irrigation during the establishment period. The faster growth of frequently irrigated trees appeared to be due primarily to better growth in the first 8 months after planting. The faster growth during this period of regular irrigation did not continue once irrigation ceased. This result contrasts with the more drought-sensitive red maple (Acer rubrum L.), for which regular irrigation in the 24 weeks following landscape planting provided for a doubling of root growth 5 months after landscape planting (Marshall and Gilman 1998). About half of this increased growth persisted 5 years later, and trunks were 35\% larger despite no irrigation after the first 24 weeks (Gilman et al 2003).

Data presented in this study must be interpreted carefully because this study was conducted in a fairly loose, agricultural field soil. This soil can by no means be construed as an urban soil typical of a downtown street side or parking lot island. Other studies found that growth improved when a large area surrounding newly planted trees (in a compacted clay soil; Nina Bassuk, unpublished) or shrubs (Schultz and Whitcomb 1975; Beeson and Keller 1998) was broken up and amended with organic matter of various types. Combined with past findings, the results of the current study appear to support the recommendation to forego adding amendments to an individual planting hole in good, noncompacted soil. There may be merit for using amendments if a large area can be amended or if soil is compacted, but more research needs to be done to test this hypothesis.

\section{LITERATURE CITED}

Banko, T.J. 1986. Growth response of azaleas transplanted into beds amended with compost sludge or pine bark. Proc. SNA Res. Conf. 31:111-113.

Beeson, R.C., and K.G. Keller. 1998. Yard waste compost as a landscape soil amendment for azaleas. J. Environ. Hortic. 19:222-225.

Bir, R.E., and T. G. Ranney. 1991. The effect of organic soil amendments on the growth and development of Kalmia latifolia. Proc. Int. Plant Propagat. Soc. 41:311-314.

Bir, R.E., J.L. Connerand, and C. Deyton. 1995. The effect of pine bark soil amendments on bed-grown hybrid ericaceous shrubs. Proc. SNA Res. Conf. 40:152-154.

Corley, W.L. 1984. Soil amendments at planting. J. Environ. Hortic. 2:27-30.

Ferrini, F, and F.P. Nicese. 2002. Response of English oak (Quercus robur L.) trees to biostimulants application in the urban environment. J. Arboric. 28:70-75.

Gilman, E.F. 2001. Effect of nursery production method, irrigation, and inoculation with mycorrhizae-forming fungi on establishment of Quercus virginiana. J. Arboric. 27:30-39. 
Gilman, E.F., and R.C. Beeson. 1992. Diurnal water stress during landscape establishment of slash pine differs among three production methods. J. Arboric. 18:281-287.

Gilman, E.F., J. Grabosky, A. Stodola, and M.D. Marshall. 2003. Irrigation and container type impact red maple five years after landscape planting. J. Arboric. 29:231-236.

Henderson-Cole, J.C., and D.L. Hensley. 1992. Influence of field-grown fabric containers and various soil amendments on the growth of green ash. J. Environ. Hortic. 10:218-221.

Ingram, D.L., R.J. Black , and C.R. Johnson. 1981. Effect of backfill composition and fertilization on establishment of container-grown plants in the landscape. Proc. Fla. State Hortic. Soc. 94:198-200.

Kelting, M.P., J.R. Harris, J.K. Fanelli, and B.L. Appleton. 1998. Effect of soil amendments and biostimulants on two-year post-transplant growth of red maple and Washington hawthorn. HortScience 33:21-23.

Marshall, M.D., and E.F. Gilman. 1998. Effects of nursery container type on root growth and landscape establishment of Acer rubrum L. J. Environ. Hortic. 15:55-59.

Pellet, H. 1971. Effects of soil amendments on growth of landscape plants. Am. Nurserymen 134:103-106.
Schulte, J.R., and C.E. Whitcomb. 1975. Effects of soil amendments and fertilizer levels on the establishment of silver maple. J. Arboric. 1:192-195.

Smalley, T.J., and C.B. Wood. 1995. Effect of backfill amendment on growth of red maple. J. Arboric. 21:247-249.

Watson, G.W. 1996. Tree root system enhancement with paclobutrazol. J. Arboric. 22:211-217.

Wehtje, G.R., J.N. Shaw, R.H. Walker, and W. Williams. 2003. Bermudagrass growth in soil supplemented with inorganic amendments. HortScience 38:613-617.

Acknowledgments. Thanks to Walt Disney World for partial funding for this project. Florida Agricultural Experiment Station Journal Series No. R-10107.

Professor

Department of Environmental Horticulture

University of Florida

Gainesville, FL 32611, U.S. 
Résumé. Durant la première et la deuxième année après la transplantation dans un sol de bonne qualité, il n'y a apparemment pas eu de bénéfices obtenus suite aux amendements faits dans le sol de remblai utilisé autour de chênes de Virginie nouvellement plantés dont le calibre de tronc était de $5 \mathrm{~cm}$; il n'y en a pas eu non plus suite à l'application d'additifs liquides au-dessus de la motte de terre. La croissance de la cime ne s'est pas accrue dans les deux premières années après la plantation suite aux amendements ajoutés au sol de remblai, et ce par rapport au arbres témoins. Dans la première saison de croissance suivant la plantation, les arbres irrigués fréquemment -3 fois par semaines durant 38 semaines - poussaient deux fois plus vite que ceux irrigués durant les trois premiers mois seulement après la plantation. Il n'y a pas eu d'effet persistant de l'irrigation sur la croissance de la cime une fois que l'irrigation eut cessée. La croissance en diamètre du tronc et en hauteur des arbres traités avec le paclobutrazol (Profile ${ }^{\mathrm{TM}}$ 2SC) a été moindre que celle des arbres avec tous les autres types de traitements, et ce en raison de l'effet régulateur du paclobutrazol. La croissance des racines dans le sol de remblai n'a pas été affectée par les amendements ajoutés au sol au moment de la plantation et n'a pas non plus été affectée par le régime d'irrigation après la plantation dans cinq des sept traitements effectués.

Zusammenfassung. Nach dem ersten und zweiten Jahr der Rückpflanzung in guten Boden gab es keinen sichtbaren Erfolg durch das Zuführen von Zusätzen zum Rückfüllboden bei der Pflanzung von Lebenseichen mit 2 inch Umfang, noch gab es irgendeinen Vorteil durch die Ausbringung von flüssigen Additiven auf den Wurzelballen. In der ersten Wachstumssaison nach der Pflanzung wuchsen die Bäume mit regelmäßiger (3 mal die Woche) Bewässerung zweimal so schnell wie die Bäume, die nur während der ersten drei Monate nach der Pflanzung bewässert wurden. Es gab keinen Effekt auf die Bewässerung bei optimalen Wachstumsraten, als diese mal ausgesetzt wurde. Der Stammdurchmesser und das Höhenwachstum bei Bäumen, die mit paclobutrazol (Profile ${ }^{\mathrm{TM}}$ 2SC) behandelt wurden, war kleiner als bei Bäumen in allen anderen Behandlungen wegen des wachstumregulierenden Effekts von Paclobutrazol. Das Wurzelwachstum in dem Rückfüllboden wurde nicht beeinflusst durch Zusätze zum Boden und wurde nicht beeinflusst durch die Bewässerung nach der Pflanzung bei 5 von 7 Behandlungen.

Resumen. Durante el primero y segundo año después del trasplante en buen suelo, no hubo beneficio aparente de añadir mejoradores al relleno del suelo alrededor de encinos de 2 pulgadas de diámetro recién plantados, ni hubo beneficio de aplicar aditivos líquidos sobre la bola de raíces. El crecimiento aéreo en los 2 primeros años después de la plantación no aumentó con los mejoradores añadidos al relleno en el suelo comparado con el control. En la primera estación de crecimiento después de la plantación, los árboles regados frecuentemente (3 veces por semana por 38 semanas) crecieron cerca el doble de rápido que los regados solamente durante los primeros tres meses después de la plantación. No hubo un efecto prolongado del riego en las tasa de crecimiento de la copa una vez éste cesó. El crecimiento del diámetro del tronco y la altura en árboles tratados con paclobutrazol (Profile ${ }^{\mathrm{TM}}$ 2SC) fue menor que en todos los otros tratamientos, debido al efecto regulador del paclobutrazol. El crecimiento de la raíz en el relleno del suelo no fue afectado por los mejoradores añadidos al relleno en la plantación y no fue afectada después de la plantación en 5 de los 7 tratamientos. 


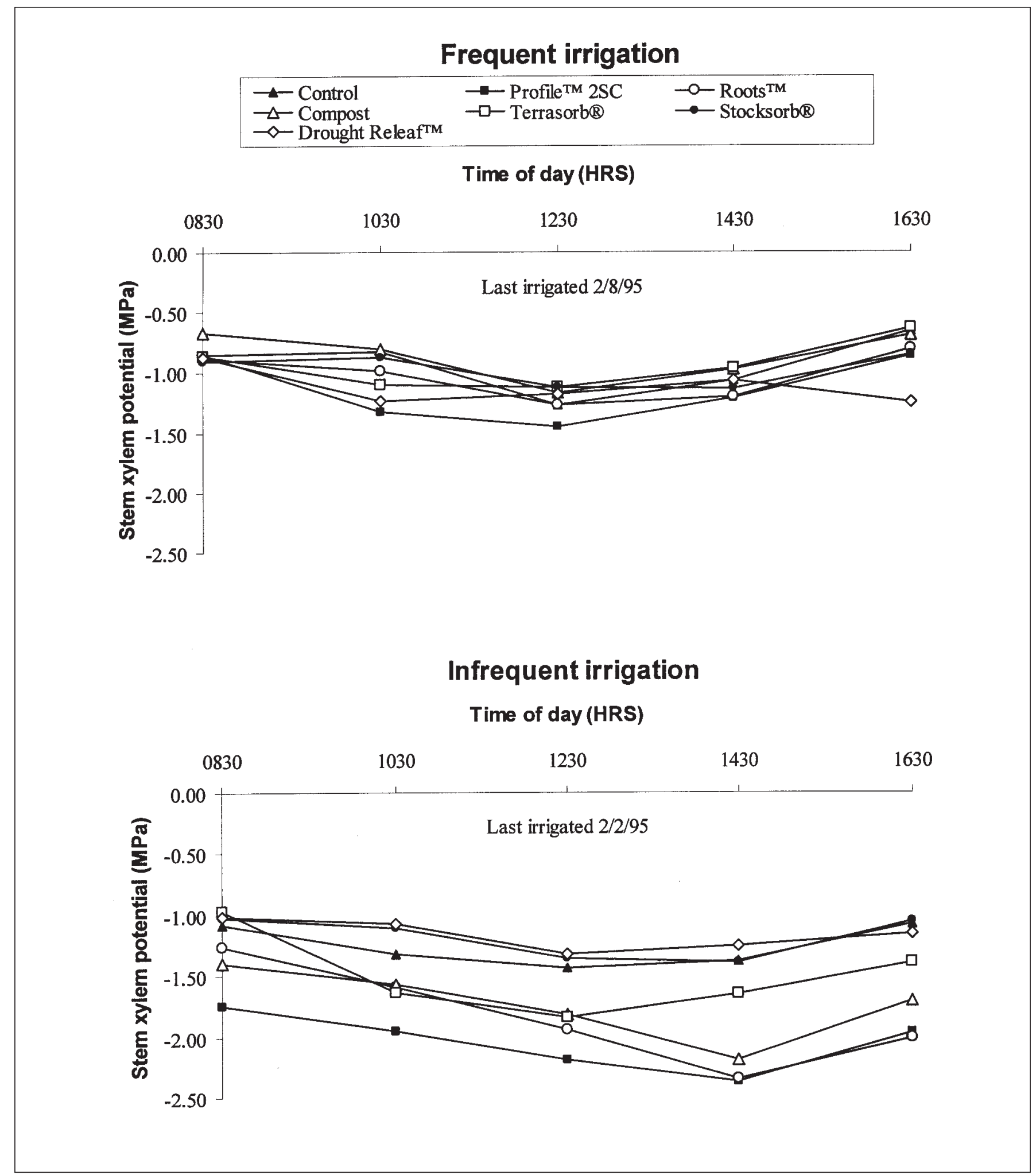

Figure 1. Stem xylem potential on live oak February 11, 1995, 5 weeks after transplanting. Each data point is the mean of five trees. Frequently irrigated trees had less negative xylem potential than infrequently irrigated trees at all times at $P<0.05$; there were no differences among backfill treatments. 


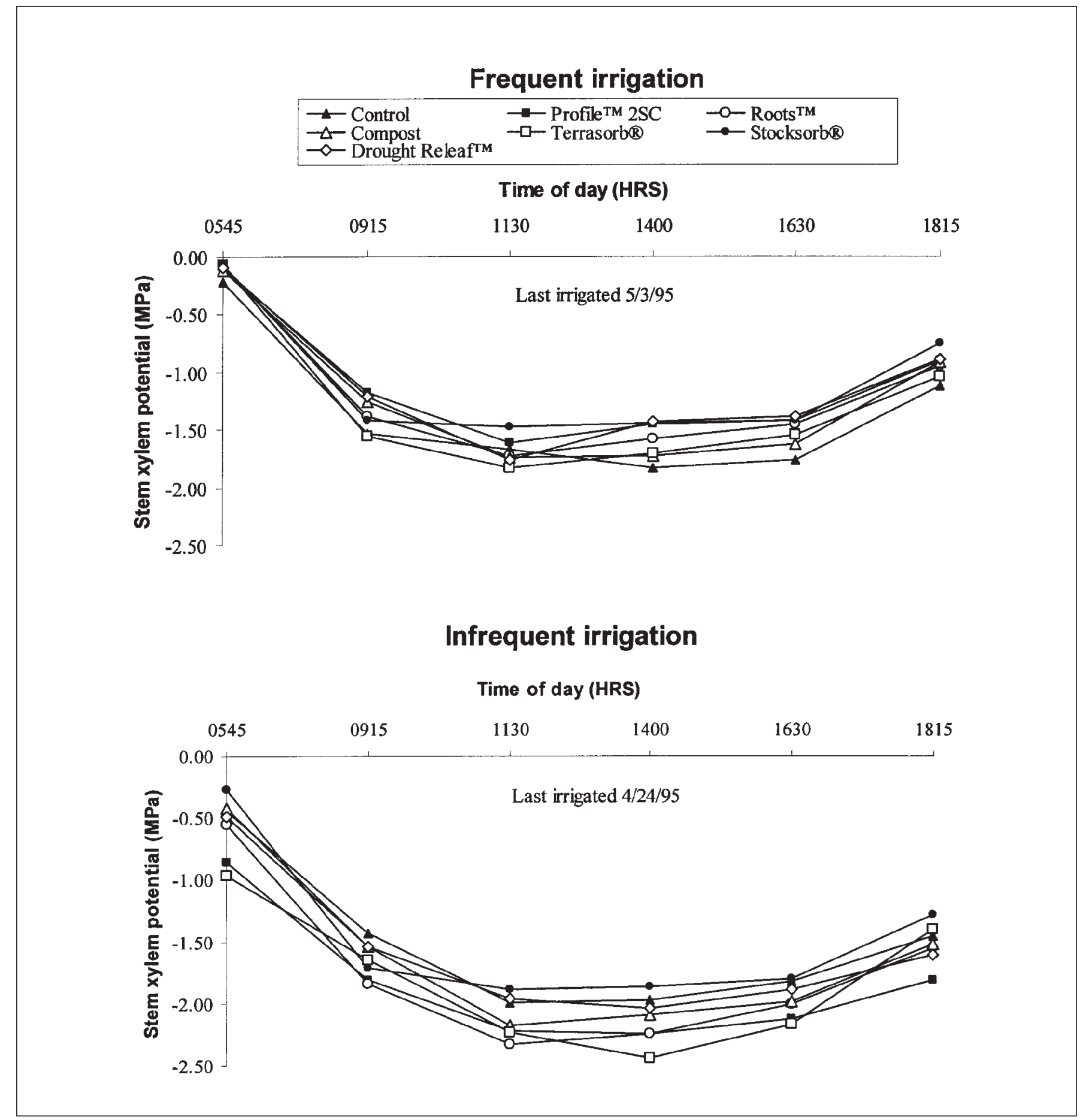

Figure 2. Stem xylem potential on live oak May 5, 1995, 15 weeks after transplanting. Each data point is the mean of five trees. Frequently irrigated trees had less negative xylem potential than infrequently irrigated trees at all times at $P<0.05$; there were no differences among backfill treatments. 


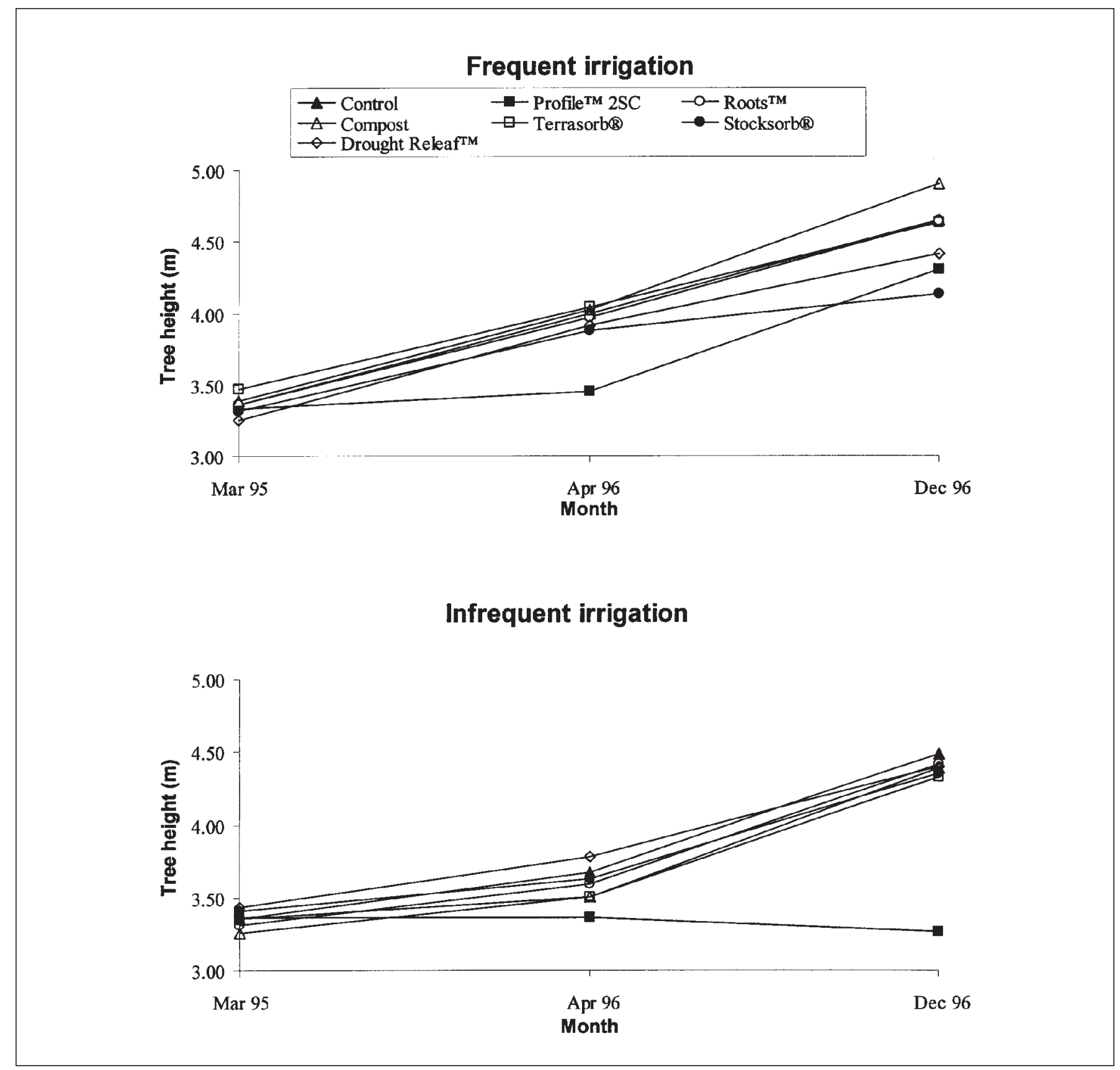

Figure 3. Effect of soil amendments and irrigation on tree height of live oak during the first 2 years after planting from containers. Each data point is the mean of 15 trees. Profile 2SC-treated trees grew slower than all others and there were no other differences $(P<0.05)$ among backfill treatments. Slope on frequently irrigated trees was greater $(P<0.05)$ than on infrequently irrigated trees the first year after transplanting. 


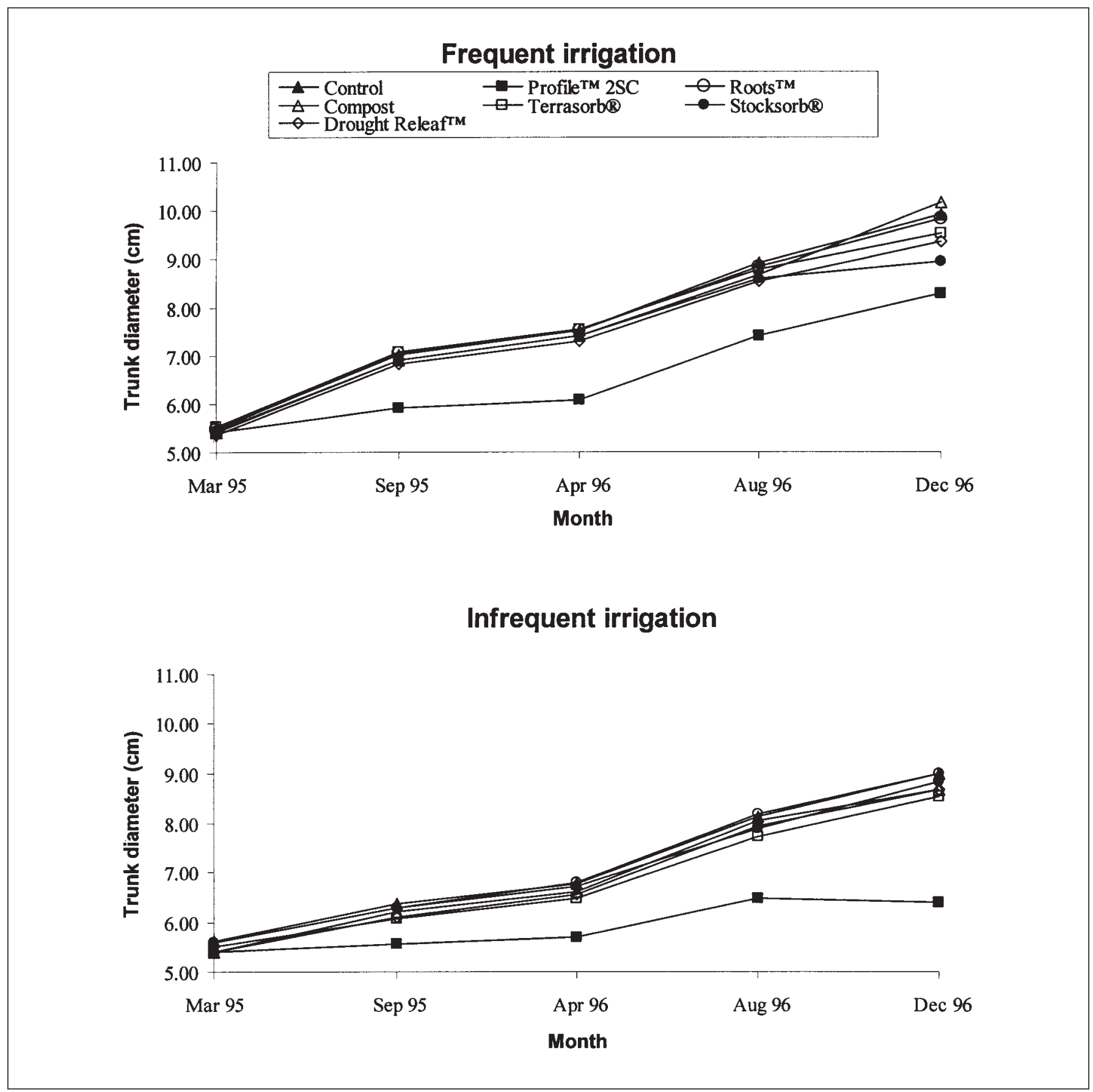

Figure 4. Effect of soil amendments and irrigation on trunk diameter growth of live oak during the first 2 years after planting from containers. Each data point is the mean of 15 trees. Profile 2SC-treated trees grew slower than all others and there were no other differences $(P<0.05)$ among backfill treatments. Slope on frequently irrigated trees was greater $(P<0.05)$ than on infrequently irrigated trees the first year after transplanting. 


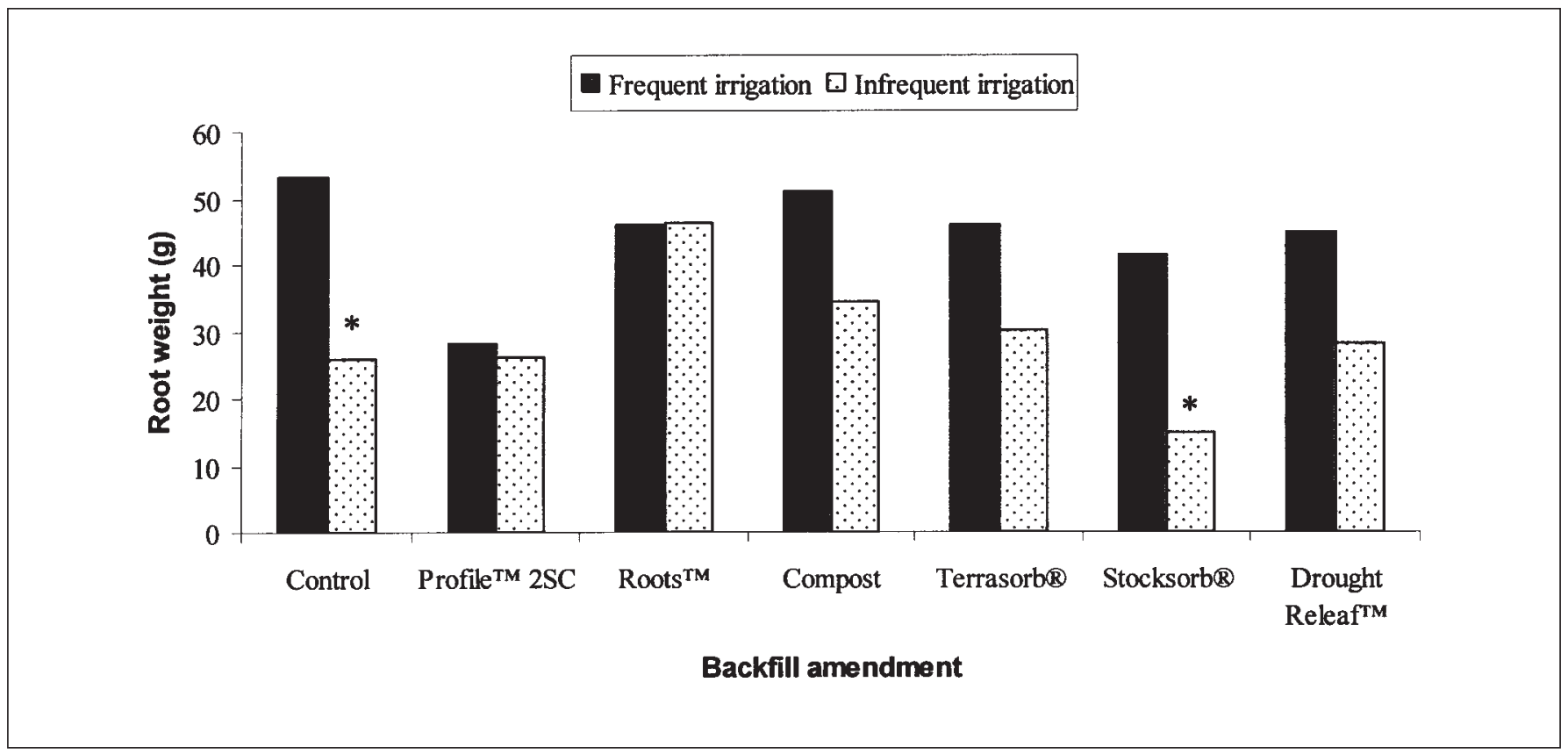

Figure 5. Root weight in the backfill soil from two one-eighth-circumference soil volumes as deep as the root ball. Asterisk indicates statistical significance between frequently irrigated and infrequently irrigated trees. 